\title{
MECHATRONIC LINE FOR ACTIVATION AND TESTING OF PRINTED ELECTRODES
}

\author{
Michal Frydrysiak, Janusz Zieba, Lukasz Tesiorowski
}

Original scientific paper

The paper describes the technology and a mechatronic device for the making and validation of textile electrodes. For making the electrodes, the digital printing method with electroconductive inks was used. The mechatronic device is a fragment of the technological line operating with a digital printer. The technological line consists of four modules designed for the printing, validation, activation and verification of the electroconductive properties of the electrodes. The first module is an intelligent camera with software designed for the analysis of the geometric shape of the electrode. The second module is a heating system for the thermal process of activation of electroconductive properties. The third module is used for checking the electroconductive properties using a multi-electrode measuring head. This type of textile electrodes designed for current muscular electrostimulation is an example of textronic products having application in rehabilitation of human.

Keywords: electrostimulation of the muscles; ink; printed; surface resistance; textile electrodes

Mehatronička linija za aktiviranje $i$ ispitivanje tiskanih elektroda

Izvorni znanstveni članak

U radu se opisuje tehnologija i mehatronički uređaj za izradu i provjeru tekstilnih elektroda. Za izradu elektroda primijenjena je digitalna metoda tiskanja s elektroprovodivim tintama. Mehatronički uređaj je dio tehnološke linije koja radi s digitalnim pisačem. Tehnološka linija se sastoji od četiri modula za tiskanje, provjeru, aktiviranje i verifikaciju elektroprovodivih svojstava elektroda. Prvi modul je inteligentna kamera sa softverom dizajniranim za analizu geometrijskog oblika elektrode. Drugi modul je sustav zagrijavanja za toplinski proces aktiviranja elektrovodljivih svojstava. Treći modul služi za provjeru električne vodljivosti primjenom mjerne glave s više elektroda. Taj tip tekstilnih elektroda namijenjenih za mišičnu elektrostimulaciju primjer je tekstroničkih proizvoda koji se primjenjuju u rehabilitaciji ljudi.

Ključne riječi: elektrostimulacija mišića; otpornost površine; tekstilne elektrode; tinta; tiskan

\section{Introduction}

Electrotherapy is an important part of physical therapy, which is used for medical purposes in various types of electrical current stimulation. Accordingly, applied electric current can cause a therapeutic effect of a stimulus and analgesic like neuromuscular stimulation, pain-killing, improvement of tissue perfusion, decreased muscle tone, easing inflammation, accelerate the absorption of edema, improve metabolism, tissue regeneration etc. [1, 2].

Different kinds of textile electrodes are used to muscles electrostimulation during the therapy. Metal or electroconductive gum is used during electrostimulation process in therapy. In this study, new textronic electrodes and whole technological line to create these electrodes were designed. New textile electrodes can replace the traditional electrodes in electro-stimulation. Textile electrodes can be part of the garment such as socks. This will facilitate the placement of electrodes on the patient's body. This type of device is reusable. The electrodes can be made by various techniques.

To the construction of textile electrodes printing technology and electroconductive inks, which consist of silver nanoparticles, were used. They are elastic and good fitted to body shape (legs or arms). The goal of research is to achieve a uniform electroconductive layer with a specific shape on the selected textile substrate.

The paper presents only the process of making the printed textile electrode. An automated system for measuring the surface resistance of the produced textile electrode is also described.

\section{Technological line to electrodes creation}

Textile electrodes can be made using various textile technologies, such as padding, vacuum sublimation or printing using electroconductive inks [3]. In the case at hand, the textile electrode printing technology has been developed. The process of making printed textile electrodes is not a single process. The production of the final product is made up of many production stages as creation, validation, activation and verification. These stages are shown in Fig. 1.

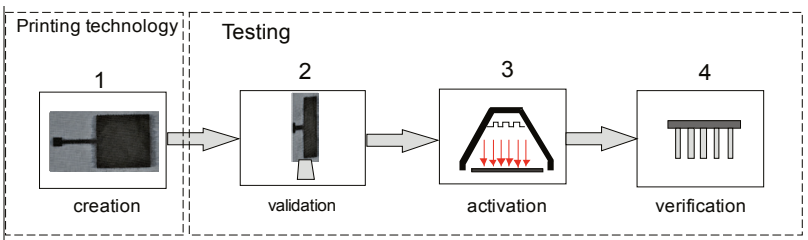

Figure 1 A modular schematic of the testing process of printing textronic electrodes for muscular electrostimulation; 1 - printing system;

2 - vision system; 3 - heaters; 4 - multielectrodes checking system

The first, most important stage is the selection of printing technology, depending on the textile substrate. For printing on foils, e.g. flexible electronic components, we have many printing techniques to choose from, as in the case of fibrous substrates, which are characterized by the variability of mass, thickness and structure. In the presented solution, the Drop on Demand printing system and Valve Jet printer machines have been selected.

Another, the second stage in making textronic muscular electrostimulation electrodes involves the validation of the electrode shape. This can be done, e.g., by comparing the print with the standard. The FZ3 H700, an advanced vision system by Omron, was used for this purpose. The third stage of textile electrode production is 
the activation of the electroconductive layer through thermal treatment. The last production stage consists of the verification of the electroconductive properties of the printed electrodes. This is one of the most important production stages. Prototype $6 \times 6 \mathrm{~cm}$ textile electrode printouts were made within the study.

For the assessment of the quality and properties of printed electrodes, a mechatronic device was constructed, which is a fragment of the technological line, as shown in Fig. 2, while the control system for this line is shown in Fig. 3. The system controlling the technological line fragment consists of a pneumatic and an electric drive, a measuring and a vision systems. The pneumatic drive includes two pneumatic servomotors. One of them drives the heater, and the other one - the measuring head. The measuring head measures the surface resistance of the made textile electrode.

The whole is controlled by an OMRON CP1LProgramable Logic Controller (PLC). For this purpose, using the lader logic programming language, a software application was made.

The device is composed of three modules. The second module includes a camera, whose purpose is to enable the visual assessment of the quality of a printed electrode. The electrode is printed on fabric that is positioned on the carriage of the device. Then, it is moved to the position under the camera with the servomotor. The camera analyzes the printed image in time tv and, depending on the print quality, it is moved in time tdh to the position under the heater. If the electroconductive print does not meet the required quality, the carriage returns to the printer's field. The heater is the third module of the device. The heater is lowered with the pneumatic servomotor 1 and textile electrode is heating in th time. After completion of the heating, the servomotor lifts the heater to the initial position. After the fixation and activation of the electroconductive layer, the testing of the electrode follows by measuring the surface resistance using the fourth module, after prior moving the carriage in time tdm to the position under the head. The head is lowered using the servomotor 2 until its elementary electrodes come into contact with the textile electrode. The measurement is done in time tm with the multielectrode head using a microprocessor measuring system with software in the LabVIEW.

The device can be extended by adding an air-tight vacuum finished product packaging feature. All modules of the device are controlled by PLCs. The parameters of the technological process are set using the Touch Panel.
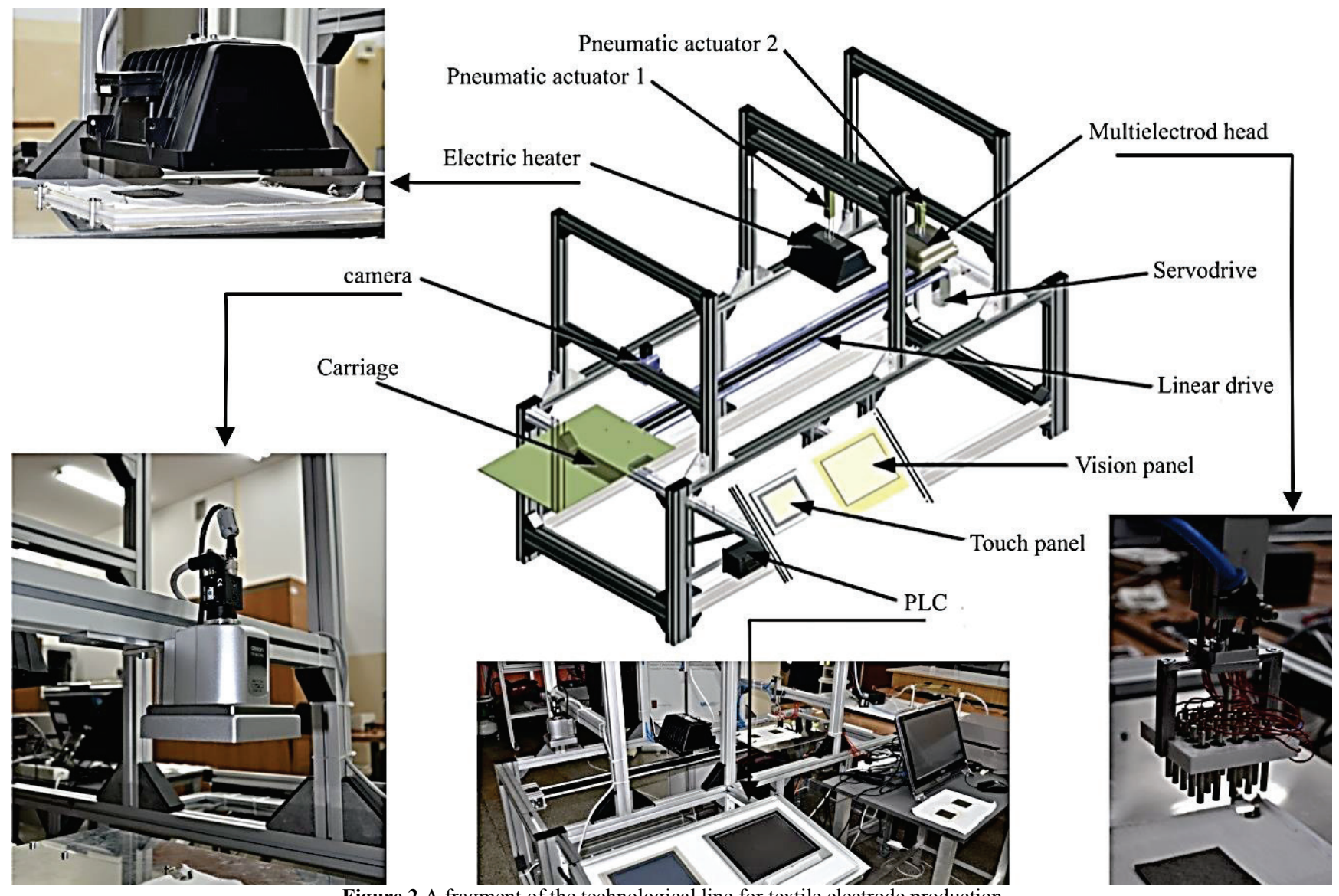

Figure 2 A fragment of the technological line for textile electrode production 


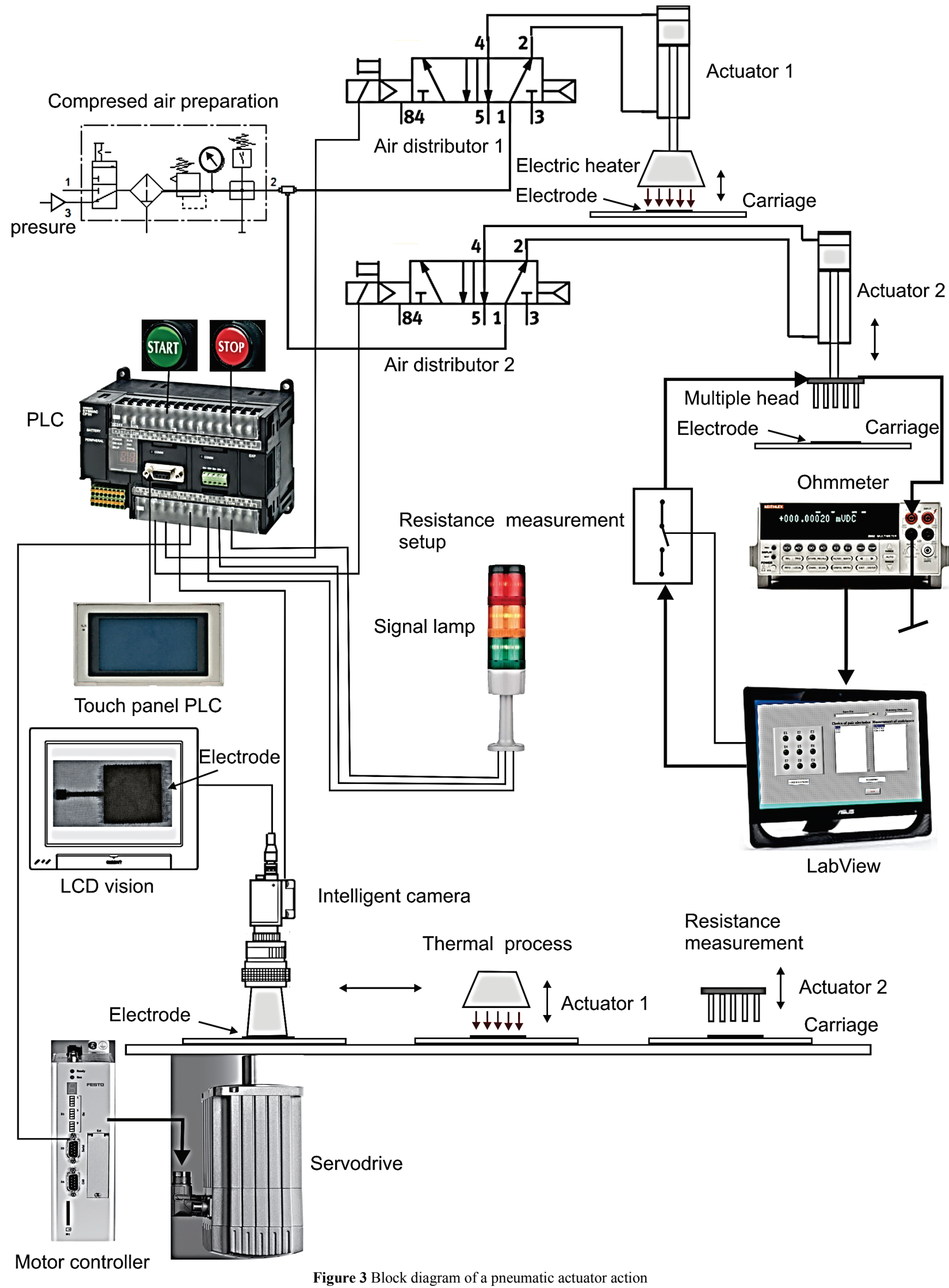




\subsection{Printing technology}

For the production of textile electrodes, different types of textile materials were used, which are described in detail in previous papers by the authors [15]. The paper presents selected cotton textile substrate and presents a printing method using a proven electroconductive ink.

The focus of the paper is on one of the textile substrate types, namely on plain weave cotton fabric.The basic information describing the textile substrate is provided in Tab. 1. Natural raw materials were selected on textile substrate. It ensures the comfort of use.

\begin{tabular}{|c|c|c|}
\hline Material & Aerial density $/ \mathrm{g} / \mathrm{m}^{2}$ & $\begin{array}{c}\text { Thickness } / \\
\mathrm{mm}\end{array}$ \\
\hline $\begin{array}{c}\text { Woven fabric } \\
\text { plain wave }\end{array}$ & 214 & 0,74 \\
\hline $\begin{array}{c}\text { Microscopic } \\
\text { photo; }\end{array}$ & $\begin{array}{c}\text { Geometrical } \\
\text { dimensions }\end{array}$ \\
$\begin{array}{c}\text { magnification } \\
3,75\end{array}$ & $\begin{array}{c}60 \times 60 \\
\mathrm{~mm}\end{array}$ \\
\hline
\end{tabular}

Electroconductive ink was used in the tests. Textile electrodes were made using a conductive silver nanoink. This ink is based on silver nanoparticles with an average size of around $10 \mathrm{~nm}$ and is dispersed in a liquid vehicle. It is highly soluble in nonpolar organic solvents and stable under atmospheric conditions at room temperature. The silver concentration in the dispersion was $50 \%$ and the viscosity could be controlled in the range of $1 \div 10 \mathrm{cP}$. Silver nanoparticles have a low sintering temperature (from 90 to $200{ }^{\circ} \mathrm{C}$ ) and can be used on inexpensive substrates, such as paper, polyester, polyimide, cotton and others. The basic information on the ink is given in Tab. 2 [15].

Table 2 The ink properties

\begin{tabular}{|l|c|}
\hline \multicolumn{2}{|c|}{ Electroconductive Ink properties } \\
\hline \multicolumn{1}{|c|}{ Parameter } & Value \\
\hline Particle size & $\sim 7 \div 10 \mathrm{~nm}$ \\
\hline Silver concentration & $\sim 50 \%$ \\
\hline Viscosity & $\sim 5 \mathrm{cP}$ \\
\hline Annealing temperature & $90 \div 200^{\circ} \mathrm{C}$ \\
\hline Annealing time & a few hours \\
\hline
\end{tabular}

For the printing process, the Drop on Demand printing system was used. The diameter of the nozzles in this type of printing head can be in the range of $80 \div 180$ $\mathrm{mm}$. A typical volume of drops can be in the range of $50 \div 250$ nanolitres. The viscosity of the ink can be in the range of $1 \div 1000 \mathrm{cP}$. An example prototype of printing electrodes with and without connectors is presented in Fig. $4 \mathrm{a}$ and $4 \mathrm{~b}$. a)

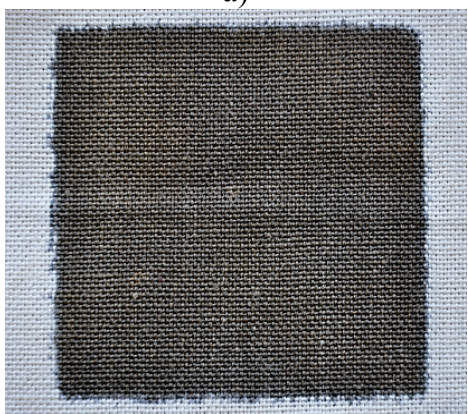

b)

Connector part printing line electroconductive area

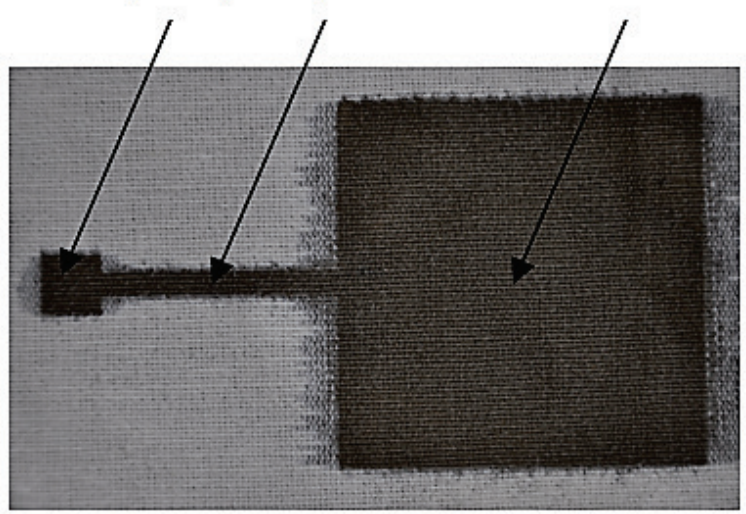

Figure 4 The printing electroconductive area (B). The prototype of textile electrode with connector part, printing line and electroconductive area.

\subsection{Omron FZ3 H700 Vision system}

Using this system, the second production stage, namely the printed electrode shape validation, is carried out. The system consists of a Central Procesing Unit (CPU) with software and a camera connected to it.The software recognizes the current print shape and compares it with the standard, while allowing for the preset tolerance factor, which in the case was $5 \%$. Current image of printed electrodes is compared with the reference image stored in the database system. This will enable the identification of errors regardless of where they occur. The schematic diagram of the measuring system of module 2 is shown in Fig. 4. Two extreme cases, which might occur during the process, are illustrated in Figs. 5a and 5b.

In the first place, the electrode print standard was defined and saved in the system's database.Then the system carries out the SIFT (Scale Invariant Feature Transform) algorithm. It distinguishes the characteristic fragments of the image, as a result of which an object description function is created. The description of the distinguished image is used for the recognition of the specific electrode shape.The characteristic fragments are found in the three-dimensional space in the form of points formed as a result of subtracting two images from each other, on which (Gauss) filtration treatments were done. The fragments occurring on the borders of the image are removed, and feature vectors described by histograms are successively created. The principle of comparison consists in excluding those fragments, for which the distance between the characteristic points is smaller than the minimum distance between these points. 


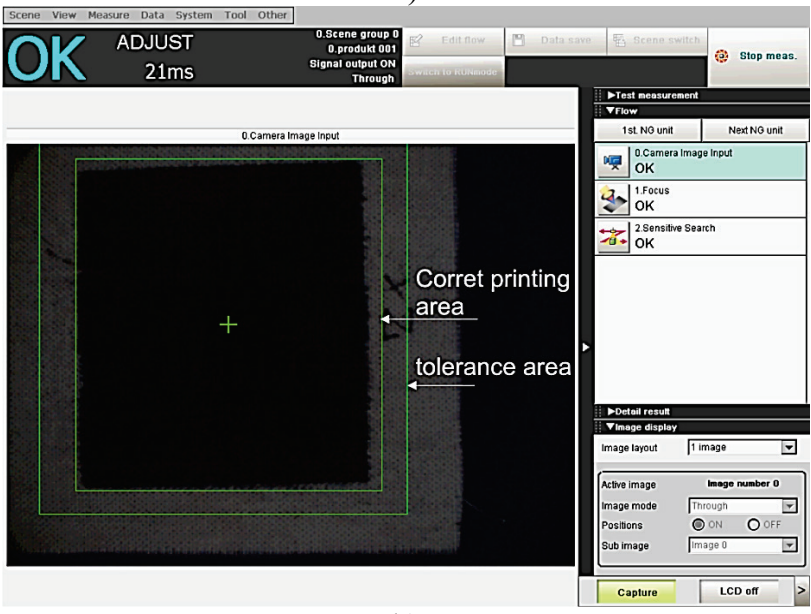

b)

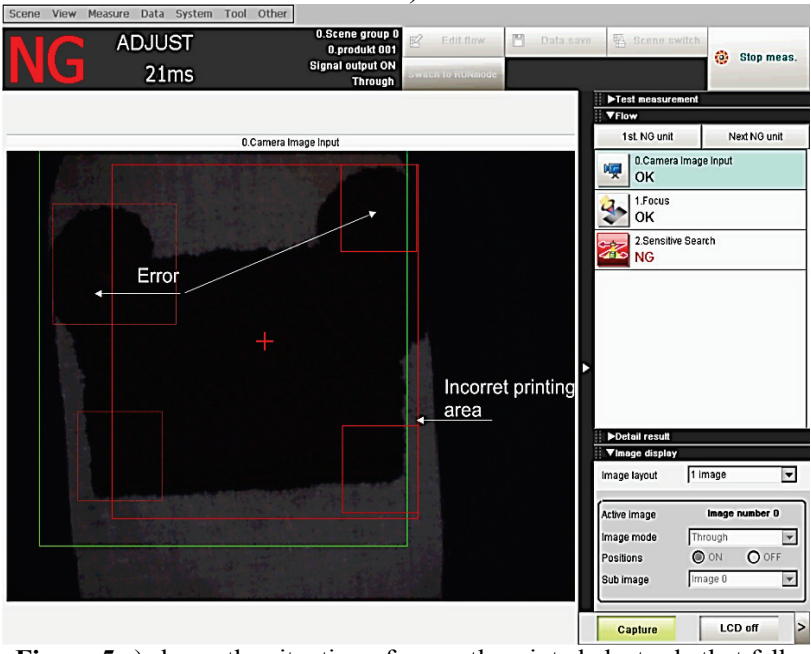

Figure 5 a) shows the situation of correctly printed electrode that falls within the specified limits; (b) illustrates a situation, where a printing error has occurred

\subsection{Heating system}

A stage indispensable in the printing electrode production technology is the thermal treatment of the prints made. The heating time and temperature are strictly dependant on many factors, such as the type of electroconductive ink or the kind of textile substrate. In the tests carried out, the samples were heated at a temperature of up to $140{ }^{\circ} \mathrm{C}$ for a period of up to 14 hours. Heating time results from ink properties. The proper heating time is required to obtain stable electroconductive properties of textiles. In the research electroconductive properties were obtained after 20 minutes but only between some points on the surface of the electrode. Extending the heating time results in a uniform surface resistance distribution at the electrode. An activation heating system is shown in Fig. 6.

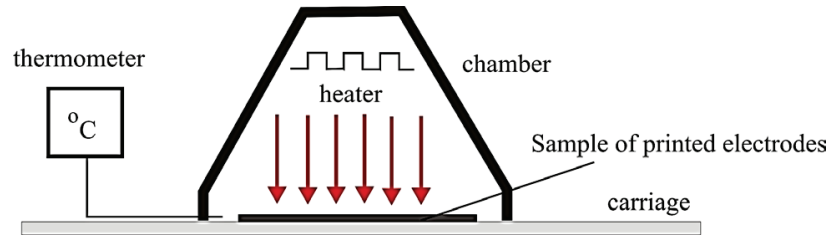

Figure 6 A schematic diagram for the measurement of temperature in the heating

\subsection{The measuring module for the evaluation of the surface resistance of textile electrodes}

A parameter important from the point of view of the correct electrostimulation process is the value of surface resistance. The producers of medical generator equipment recommended that the surface resistance of electrodes at between any two points on the electrode should be smaller than $300 \Omega$. This is connected directly with the good electroconductive properties of printing electrodes and indirectly with ink electroconductive properties. If the resistance is higher, the flow of current could cause high temperature to occur on the electrode. This could be dangerous, as it may burn the skin.

In the case of textile electrodes, the exact determination of the electrode resistance is difficult, since the electroconductive textile material has an uneven resistance distribution [8]. At one point the resistance value is a few $\Omega$, while at the other point the electrode resistance can reach a value in the order of several $\mathrm{M} \Omega$.

Prior to each electrostimulation process, the resistance of such an electrode should be measured. This can be done by the one-point method, whereby one probe is fixed, while the other probe is positioned punctually on the electrode being tested [MARP Electronic Sp. z o.o., 2007]. The evaluation of the surface resistivity can also be made by the method described in standard PN-EN 11491:2008. A sample of the textile product is placed on a flat insulating base. Then a system of measuring probes is arranged on the sample, which consists of a cylindrical and a ring-shaped probes positioned coaxially relative to each other. A resistance measurement is achieved by connecting the measuring wires of an ohmmeter to the terminals of these measuring probes [12]. The methods described above do not provide information about the distribution of surface resistance and, in some instances, it is not possible to attain the measurement repeatability conditions. In order to be able to take measurement of surface resistance distribution on the textile electrode under the repeatability conditions, a microprocessor system for measuring surface resistance using a multipoint probe was constructed. A block diagram of this system is represented in Fig. 7 [7].

The measuring system consists of 9-element matrix of electrodes designated by E1 through E9. To each of the electrodes, a signal is delivered from the contacts of relays $\mathrm{R} 1 \ldots \mathrm{R} 18$. The multi-point electrode is placed on the test textile sample, while exerting the appropriate pressure to assure the best contact of the electrode with the sample. Two relay contacts are connected to each electrode. This provides the possibility of measuring the resistance between any arbitrarily chosen electrodes in the matrix.

The terminals of each of the contacts are connected to the measuring buses designated as A and B. Any resistance-measuring multimeter equipped with a USB interface can be connected to these buses. In the case at hand, a precision multimeter supplied by Keithley 2002 was used for resistance measurement. The information on the measured resistance is sent through the USB interface to the PC. The PC sends individual electrode switch-on commands to the microcontroller. The microcontroller communicates through the $\mathrm{I} 2 \mathrm{C}$ interface with the control 
system which extends the number of microcontroller outputs, since 18 outputs is needed for the complete handling of all electrodes. The control system outputs from S1 through S18 are connected to a set of relays $\mathrm{R} 1 \ldots \mathrm{R} 18$ that switch on individual electrodes from E1 through E9. The microcontroller was programmed for operation using the $\mathrm{C}$ programming language. In order to take a resistance measurement, e.g., between the electrodes E3 and E5, the appropriate relays should be switched on, whose contacts are connected to the outputs designated as $\mathrm{A}$ and $\mathrm{B}$.

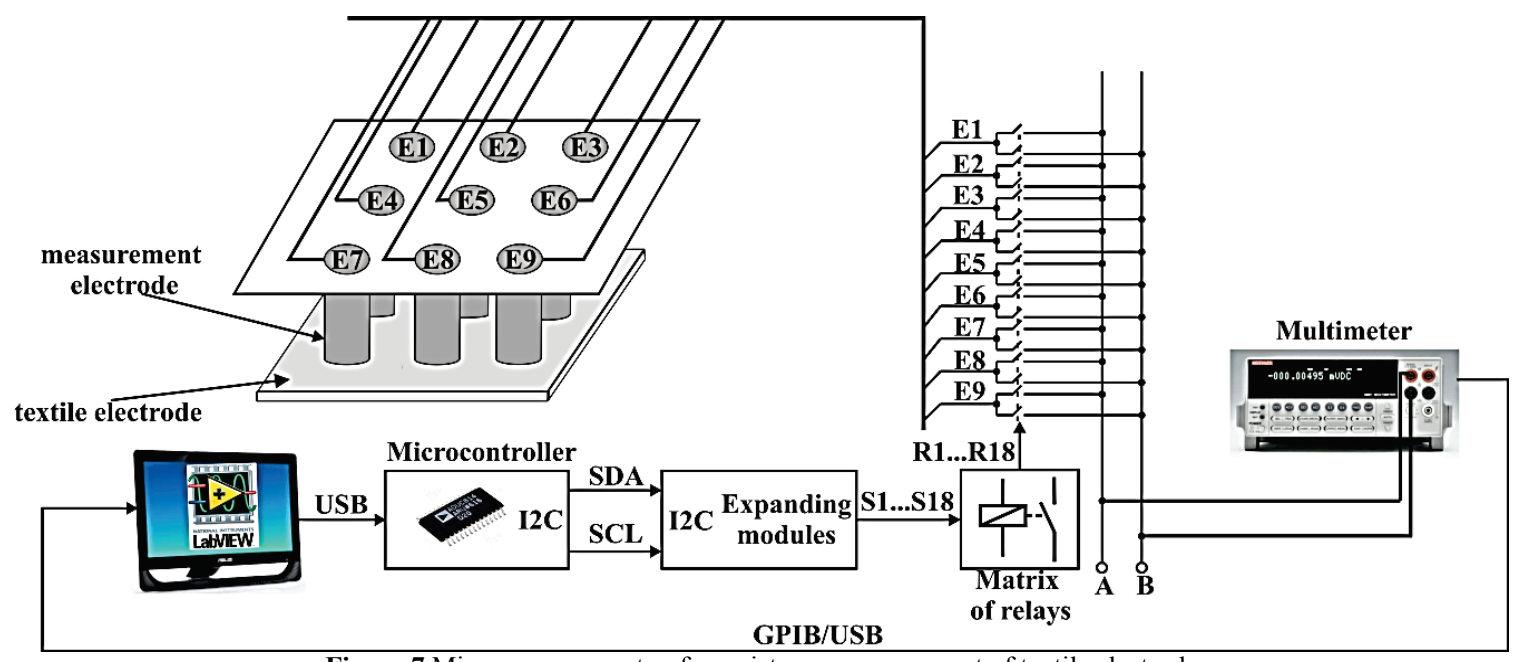

Figure 7 Microprocessor setup for resistance measurement of textile electrode

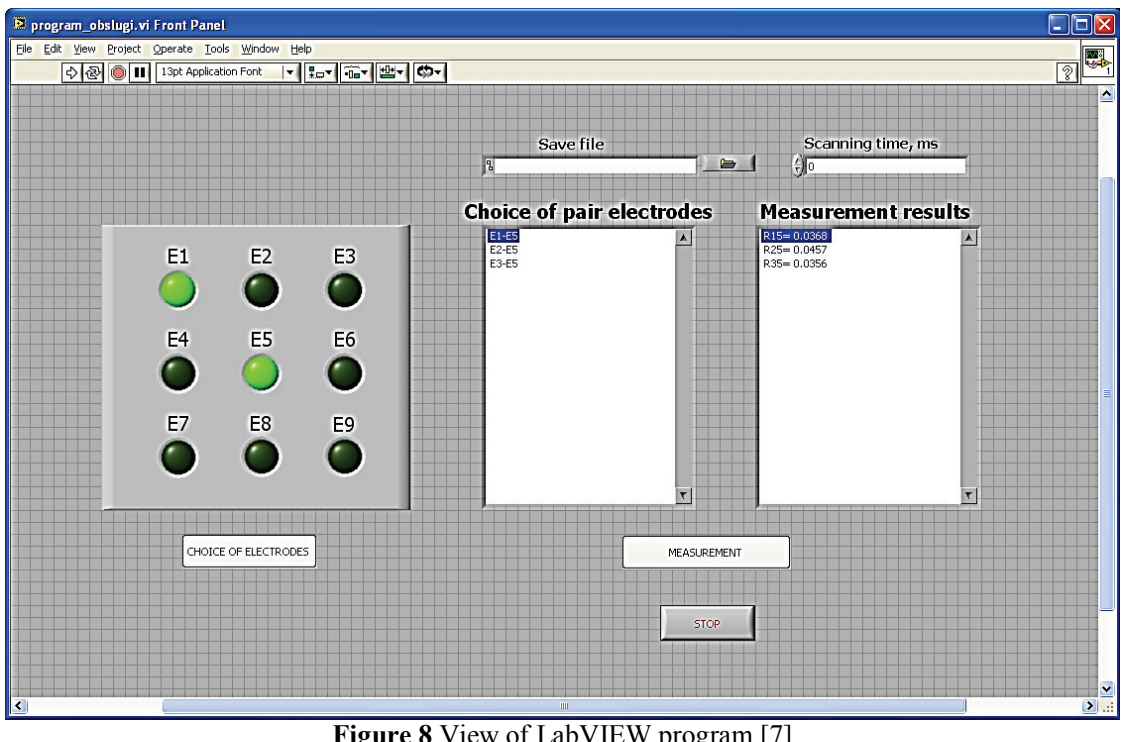

A similar procedure is true for other resistance measurement configurations. The system is characterized by an automatic measurement mode, as it provides the possibility of measuring the resistance between two points in a repeatable manner and with the identical force of pressing the electrodes against the textile sample. The measuring system is controlled from a computer via a software application created in the LabVIEW environment. The application's window for the operation of the measuring system is shown in Fig. 8 [7].

Prior to taking a measurement, the appropriate pair of electrodes is chosen, confirming the selection made by pressing the "CHOICE OF ELECTRODES" button. The selected electrode pair will be shown in the "Electrode Pair Selection" window. After pressing the "MEASUREMENT" button, the sequential measurement of resistance between the previously selected electrodes will take place with the preset time of scanning between successive measurements. The results of successive measurements, expressed in $\Omega$, are displayed in the "Resistance Measurement" window and saved in the file defined in the "Save in File" field. The running of the program is stopped with the "STOP" button [7].

\subsubsection{Measurements of the electroconductive properties of the produced textile electrodes}

As an example, measurement results for the resistance of fabric with a silver overprint are given. Such fabric can find application in the construction of muscular electrostimulation electrodes. The basic parameters characterizing the fabric are summarized in Tab. 1. Measurement model parameters have been proposed, which have an effect on the resistance measurement of textile materials. The proposed qualitative model for the measurement of the surface resistance of textile electrodes 
is illustrated in Fig. 9, where the respective quantities are designated as follows:

- $\quad I$ - Current (input quantity)

- $\quad R$ - resistance, (output quantity)

- $T$ - ambient temperature

- $R H$ - air relative humidity.

- $U$ - voltage

- $A$ - measurement area

- $\quad M$ - material, (all constant quantities)

- $\quad P$ - atmospheric pressure

- $\quad E$ - electromagnetic disturbance

- $V_{\mathrm{A}}-$ air velocity.

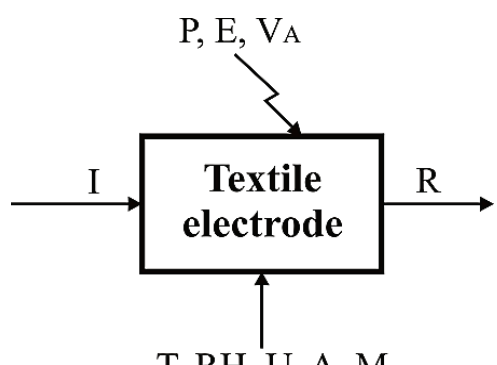

T, RH, U, A, M

Figure 9 Qualitative model of resistance measurement the textile electrode [7].

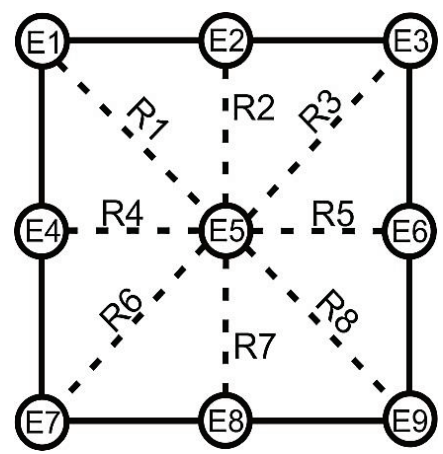

Figure 10 Distribution of measurement electrodes on textile electrodes [7]

Fig. 10 shows the arrangement of 9 measuring electrodes on the textile sample surface, along with the constituent resultant resistances of the textile electrode,
R1-R8. During testing, the value of those resultant resistances was determined with respect to the central electrode E5. The results of successive resistance measurements taken using the multi-point probe are represented in Fig. 11.

The paper presents only selected results.

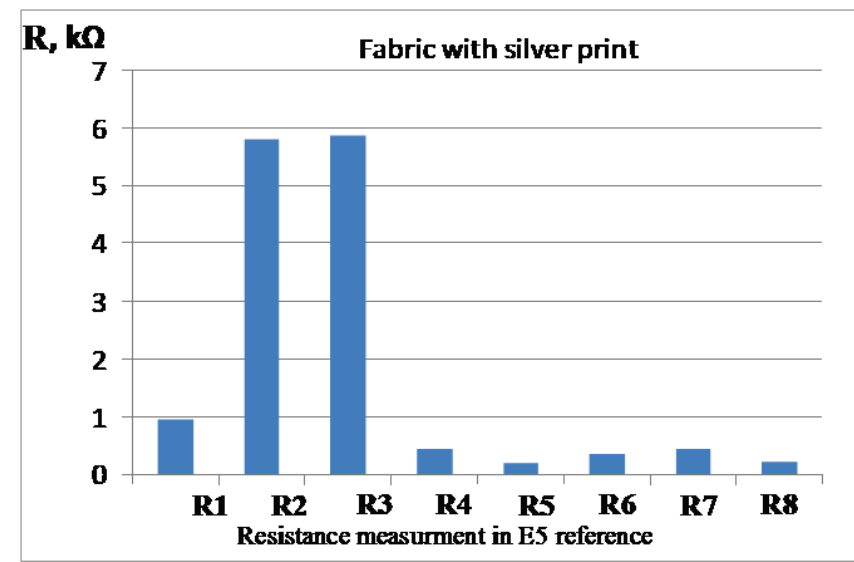

Figure 11 Chosen resistance measurements in case of fabric with silver print

The test results indicate an unevenness of the surface resistance of the textile print fabric. The largest resistance value is at a level of several $\mathrm{k} \Omega$, whereas in the remaining electrode areas the resistance ranges from 194 to $953 \Omega$. The unevenness of resistance is associated with the uneven thickness of ink printed on the fabric surface and non-uniformity of the textile substrate. A visualization of the distribution of local electrode surface resistances is shown in Fig. 12. This electrode has got correct electroconductive properties and can be used in electrostimulation process.

The paper presented tests of several types of textile substrates intended for textile bands for electrostimulation. They differed in material and structure. Several types of electrconductive inks were also tested. This article presents only a selected case using cotton fabric and nano silver based ink.

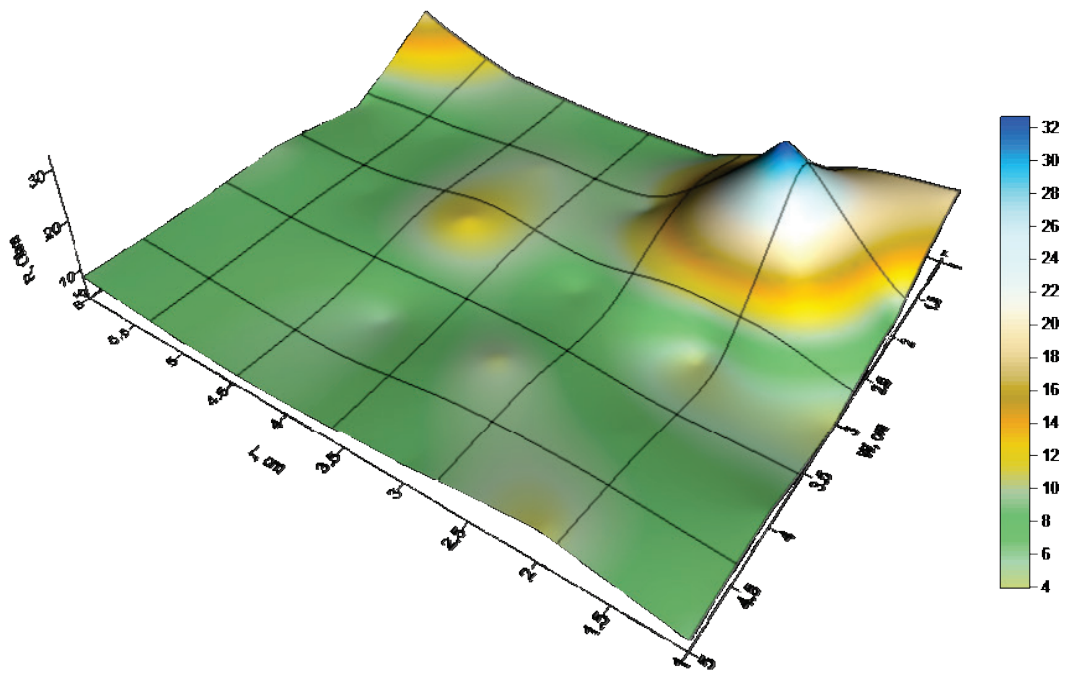

Figure 12 An example of resistance distribution on the surface of the textile electrode 


\section{Discussion and conclusions}

In this paper the authors present a prototype of a technological line for the production of textile electrodes. The authors do not focus on the problems associated with printing inks on textiles.

Textile electrodes provide an alternative solution that can substitute for muscular electrostimulation electrodes existing in the market. The new type of electrodes requires a technological line to be created, which will enable the production of the electrodes and measurement of their electroconductive properties.

The paper has set out the process of producing printed textile electrodes. Individual stages of the printing process are carried out in the appropriate time. The most important is the selection of the conductive ink. A dedicated printer with printing heads designed for that specific ink is also required. When creating the line, a specialized vision system supplied by OMRON was used, which enabled the preliminary verification of the printed textile electrodes. Textile electrodes that do not meet the appropriate dimensions and shape geometry are rejected by the system. Heating of the printed electrode for the appropriate time and at the proper temperature results in the formation of electroconductive properties. The final stage of production of the textile electrode is the measurement of its surface resistance. The recommended value of resistance between any arbitrarly chosen points on the electrode surface is $300 \Omega$. When measuring, exerting pressure with the identical force and taking measurements in many points is essential. Even a punctual deviation of resistance from the prescribed value may lead to localized burns during the course of electrostimulation. All these requirements are met by using the microprocessor system described in the paper. Measurements on a sample of the printed textile electrode were also taken. An unevenness of the magnitude of resistance on the electrode surface was found. This might be caused by the uneven method of electrode printing and heating.

The presented prototype mechatronic line enables production of textile electrodes in a reproducible operation with high quality. This results from the visual inspection of the shape and properties of the electroconductive electrodes. The line allows changing of technological parameters such as heating temperature depending on the applied ink. This technological line may be extended f.e. by the packaging module (lamination). Technological line will also help to increase productivity by eliminating to a minimum participation of the operator in the process.

\section{Acknowledgements}

This work is (partially) supported by Structural Founds in the frame of the project titled "Textronic system to electrical stimulation of muscles" financed by Operational Programme Innovative Economy, 2007-2013, Sub-measure 1.1.2.

\section{References}

[1] Sylwanowicz,W.; Michalik, A.; Ramotowski, W. Human anatomy and physiology (in Polish), PZWL, Warsaw, 2000.
[2] Traczyk, W. Human physology (in Polish), PZWL, Warsaw, 1992.

[3] Stempień, Z.; Gniotek, K.; Zięba, J.; Tokarska, M.; Frydrysiak, M.; Tęsiorowski, Ł. Textile - based printed electrodes for muscles electrostimulation, Fiber SocietySpring (2011) Conference, ISBN 978-962-367-7196, Hong Kong, China, 2011.

[4] Pawlak, R.; Korzeniewska, E.; Frydrysiak, M.; Zięba, J.; Tęsiorowski, Ł.; Gniotek, K.; Stempień, Z.; Tokarska, M.; Using Vacuum Deposition Technology for the Manufacturing of Electro-Conductive Layers on the Surface of Textiles. // Fibres \& Textiles in Eastern Europe. 20,2(91)(2012), pp. 68-72

[5] Gniotek, K.; Stempień, Z.; Zięba, J. Textronics - new science area (in Polish). // Textiles Review - Textiles, Garments, Leather. 2(2003), pp. 17-18.

[6] Zięba, J.; Frydrysiak, M.; Gniotek, K. Textile electrode to electrostimulation, Łódź (2008), Patent no P-384676.

[7] Tęsiorowski, Ł.; Frydrysiak, M.; Zięba, J. Microprocessor system to evaluation the surface resistance of textile electrodes used for electrical stimulation of muscles. // Electrical Review. 88, 2 (2012), pp. 191-193.

[8] Hersh, S.; Mongomery, P. Electrical Resistance Measurements on Fibers and Fiber Assemblies. // Textile Research Journal. 22, 12(1952), pp. 805-818. DOl: 10.1177/004051755202201207

[9] Banaszczyk, J.; De Mey, G.; Schwarz, A.; Van Langenhove L. Current Distribution Modelling in Electroconductive. // Fabrics, Fibres \& Textiles in Eastern Europe. 17, 2(2009), pp. 28-33.

[10] Halperin, S. A. The Difference Between Surface Resistance and Surface Resistivity. // EvaluationEngineering. 6, (1996), pp. 49-50.

[11] Asanovic, K. A.; Mihajlidi, T. A.; Milosavljevic, S. V.; Cerovic, D.; Dojcilovic, J. R. Investigation of the electrical of some textile materials. // Journal of Electrostatics. 65, 3(2007), pp. 162-167. DOI: 10.1016/j.elstat.2006.07.008

[12] PN-EN 1149-1:2008, Protective clothing - Electrostatic properties - Part 1: Test method for surface resistivity.

[13] Frydrysiak, M.; Zięba, J.; Tesiorowski, Ł.; Tokarska, M. Textronic matrix of electrode system to electrostimulation. $/ / 7^{\text {th }}$ IEEE International Symposium on Medical Measurements and Applications MeMeA 2012, pp. 149. 153.

[14] Frydrysiak, M.; Tesiorowski, L.; Zięba, J. The technological line to textronic electrodes production. $/ / 19^{\text {th }}$ Structure and Structural Mechanics of Textiles Conference, Czech Republic, December, 2012.

[15] Stempień, Z.; Gniotek, K.; Zieba, J.; Tokarska, M.; Frydrysiak, M.; Tesiorowski, L. Textile-based printed electrodes for muscles electrostimulation. // Fiber Society Hong Kong Conference, 2011.

\section{Authors' addresses}

Michal Frydrysiak, PhD Eng., Corresponding author Janusz Zięba

Lukasz Tesiorowski

Lodz University of Technology,

Department of Architecture of Textiles

116 Zeromskiego St., Lodz, 90-924 Poland

Fax 48426313343

E-mail: michal.frydrysiak@p.lodz.pl

E-mail: janusz.zieba@p.lodz.pl

E-mail: lukasz.tesiorowski@p.lodz.pl 